\title{
Prefrontal cortex cell proliferation of adult rats after chronic stress treated with ethanolic extract of Centella asiatica (L) Urban.
}

\author{
Yuniasih Mulyani Jubeliene Taihuttu ${ }^{1}$, Ginus Partadiredja2 ${ }^{2}$, Dwi Cahyani Ratna Sari ${ }^{3}$, \\ ${ }^{1}$ Faculty of Medicine, Universitas Pattimura, Ambon, ${ }^{2}$ Department of Physiology, \\ ${ }^{3}$ Department of Anatomy, Embryology, and Anthropology, Faculty of Medicine, \\ Universitas Gadjah Mada, Yogyakarta
}

DOI: http://dx.doi.org/10.19106/JMedSci004801201601

\begin{abstract}
The decrease of proliferation level of cells in several regions of adult brain is found after stress exposure. One of such area is prefrontal cortex. Herbal medicine as antistress has been used widely. Centella asiatica (L) Urban extract was reported to have potent compounds to increase brain function. The objective of this study is to investigate the effects of ethanolic extract $C$. asiatica on cell proliferation of the adult prefrontal cortex in rats (PFC) after chronic stress. Adult male Sprague-Dawley rats, weighing 260-390 $\mathrm{g}$ were randomly assigned into six experimental groups, with five rats per group, i.e. Group 1 as nomal control without chronic stress, Group 2 as stress control, Group 3 as positive control given fluoxetine, Group 4-6 as treatment groups given 150; 300 and 600 of ethanolic extrac $C$. asiatica, respectively. Extract were administered orally to the rats following a period of restraint duration of 6 hours/day for 21 days. Bromodeoxyuridine (BrdU) immunohistochemistry was used to label the proliferated cells. Physical fractionator method was used to estimate the total number of proliferated cells. One-way analysis of variance (ANOVA) followed by Tukey post hoc test was used to evaluate the difference between groups. BrdU-labeled cells on medial prefrontal cortex were as follows: $1715.3 \pm 1345.1$ (Group 1), 2659.2 \pm 2250.6 (Group 2), $4077.4 \pm 2415.3$ (Group 3), $1784.1 \pm 908.3$ (Group 4), 3056.6 \pm 4263.3 (Group 5), and 2153.4 \pm 2259.4 (Group 6). No significance difference between groups was observed $(p>0.05)$. In conclusion, the administration of ethanolic extract of $C$. asiatica does not influence cell proliferation on prefrontal cortex of rats after chronic stress.
\end{abstract}

\section{ABSTRAK}

Penurunan tingkat proliferasi sel di beberapa daerah otak orang dewasa ditemukan setelah terpapar adanya stres. Salah satu daerah tersebut adalah korteks prefrontal. Obat herbal sebagai antistres telah digunakan secara luas. Ekstrak pegagan (Centela asiatica (L) Urban dilaporkan mengandung senyawa yang potensial meningkatkan fungsi otak. Penelitian ini bertujuan untuk mengkaji pengaruh pemberian ekstrak etanol $C$. asiatica terhadap proliferasi sel prefrontal korteks (PFC) tikus dewasa setelah dibuat stres kronik. Tikus jantan dewasa galur Sprague-Dawley, berat 260-390 g secara acak dibagi menjadi 
enam kelompok dengan lima ekor tikus setiap kelompok. Kelompok kontrol normal tanpa stres kronik (Kelompok 1), kelompok kontrol stres (Kelompok 2) diberikan solusi PGA, kelompok kontrol positif (Kelompok 3) diberi fluoksetin, kelompok perlakuan (Kelompok 4-6) diberi ekstrak etanol pegagan dosis 150; 300 dan $600 \mathrm{mg} / \mathrm{kg} \mathrm{BB}$. Obat diberikan secara oral setelah induksi stres kronik selama 6 jam/hari selama 21 hari. Imunohistokimia bromodeoxyuridine (BrdU) digunakan untuk melabel sel yang beproliferasi. Metode fractionator fisik digunakan untuk estimasi jumlah total sel yang proliferasi. Analisis varian (ANAVA) saju jalan dilanjutkan dengan tes post hoc Tukey digunakan untuk mengetahui perbedaan antar kelompok. Sel positif BrdU pada medial prefrontal cortex adalah sebagai berikut: 1715,3 \pm 1345,1 (Kelompok 1), 2659,2 \pm 2250,6 (Kelompok 2), 4077,4 \pm 2415,3 (Kelompok 3), 1784,1 \pm 908,3 (Kelompok 4), 3056,6 \pm 4263,3 (Kelompok 5), 2153,4 $\pm 2259,4$ (Kelompok 6). Hasil ANAVA menunjukkan tidak ada perbedaan signifikan antar kelompok ( $p>0,05)$. Dapat disimpulkan bahwa pemberian ekstrak etanol pegagan tidak mempengaruhi proliferasi sel korteks prefrontal tikus setelah induksi stres kronik.

Keywords: prefrontal cortex - adult proliferation - C. asiatica - ethanol extract - antistress

\section{INTRODUCTION}

The brain is the key to interpret and respond to potentially stressful events throughout life. Repeated stress will affect number of brain regions, especially corticolimbic structures such as hippocampus, prefrontal cortex and amygdala. ${ }^{1}$ The changes of these structures can disrupt cognitive and emotional functions resulting in various disorders, most notably depression, schizophrenia and post traumatic stress disorder (PTSD). ${ }^{1,2}$ Stress also induces structural morphology neuronal alteration. ${ }^{3,4}$ Other structural disruptions are the rearrangement of pyramidal layers II-III apical dendrites caused by chronic glucocorticoid administration, ${ }^{4}$ atrophy of dendrite branching and loss of dendritic spines, atrophy of external prelimbic and infralimbic region of medial prefrontal cortex ${ }^{5}$ and apical dendrite remodeling in medial prefrontal cortex (mPFC). This remodeling causes reduction in the number and length of apical branching and suppresses mPFC neurogenesis which results in structural asymmetry ${ }^{3}$ due to proliferation rate differences in both hemispheres. ${ }^{5}$ Stress also can affect hippocampus and prefrontal cortex (PFC) networking by reducing long term potentiation (LTP) induction, PFC cell atrophy, disrupting working memory and stimulus processing. The cognitive function such as decision making, rule learning, behavior flexibility are also affected by stress. Stress has profound effects on structural changes of PFC. 6,7

Proliferation is the part of cytogenesis that marked by the existence of some new cells in a short period, about two hour. Rate of cytogenesis is affected by environmental factors such as stress, endocrine, and pharmacological stimulations such as antidepressant and psychotropic drugs administration. $^{8}$ Long term administration of antidepressant (2-4 weeks) can increase number of 5-bromo-2-deoxyuridine (BrdU) labeled cells, a cell proliferation marker in hippocampus and prefrontal cortex. ${ }^{1,8}$ Antidepressant can also increase the number of neurons in hippocampus. ${ }^{9}$ Unfortunately, studies have confirmed that antidepressants are no more effective after long administration and have serious side effect such as suicide. 
Therefore, a new or alternative agent is needed.

Some medicinal plants have been used traditionally as antidepressants in several regions in the world and potentially to developed as alternative treatment. ${ }^{10}$ Centella asiatica L., locally name pegagan, is one of Indonesian medical plants that has been used traditionally as antidepressant for a long time. ${ }^{11}$ The ethanol extract of $C$. asiatica L. was proven to have sedative effect and can increase cognitive functions in animal model. ${ }^{12}$ In addition, this plant has antiinflammatory active constituents that can stimulate proliferation in healing injury, ${ }^{13}$ and increase brain's higher function in young and adult mice. ${ }^{14}$ This study was conducted to evaluate the effect of ethanolic extract of C. asiatica L. on cell proliferation of PFC in adult rats.

\section{MATERIALS AND METHODS}

\section{Animal}

This was purely experimental research with posttest only control group design. Thirty adult male rats Sprague-Dawley aged 12-16 weeks with body weight 260-390 g obtained from National Agency of Drug and Food Control, Republic of Indonesia were used in this study. The rats were maintained in the animal house of the Department of Anatomy, Embryology, and Anthropology, Faculty of Medicine, Universitas Gadjah Mada under controlled conditions of light/ dark cycle (12:12) at temperature of $30 \pm 2{ }^{\circ} \mathrm{C}$ and humidity of $50 \pm 10 \%$. They were fed on standard rat food, AD II purchased from PT Wonokoyo Jaya Group, Surabaya, East Java and allowed water ad libitum. Two to three animals were housed together in a $40 \times 30 \times 15$ $\mathrm{cm}$ polypropylene cage. Animal handling and experimental procedure were approved by the Medical and Health Research Ethics Committee (MHREC), Faculty of Medicine, Universitas Gadjah Mada, Yogyakarta.

\section{Ethanolic extract of $C$. asiatica $\mathrm{L}$. preparation}

Whole plants of $C$. asiatica L. were purchased from CV Merapi Farma Herbal, Yogyakarta. The plants were then washed and oven dried at $50{ }^{\circ} \mathrm{C}$. The dried plants were powdered and used for extraction. Two hundred grams of the powder were macerated with $70 \%$ ethanol for 24 hours and filtered. This maceration was repeated thrice. All filtrates were collected and evaporated using rotary evaporator to obtain dried ethanolic extract. The extract was dissolved in $2 \%$ pulvis gummic arabicum (2\% PGA) before administering to the animals.

\section{Experimental procedures}

Experimental groups

Animals were divided into six groups of five animals each. Group 1 served as normal control that not underwent any stress procedure. Group 2 served as restraint stress control that subjected to a 21 day chronic restraint stress procedure. Group 3 served as positive control that received a dose of $10 \mathrm{mg} /$ $\mathrm{Kg}$ Body Weight (BW) of fluoxetine orally for 21 days along with chronic restraint stress. Group 4 received a dose of $150 \mathrm{mg} / \mathrm{Kg} \mathrm{BB}$ of C. asiatica L. ethanolic extract orally for 21 days along with chronic restraint stress. Group 5 received a dose of $300 \mathrm{mg} / \mathrm{Kg}$ BB of $C$. asiatica $\mathrm{L}$. ethanolic extract orally for 21 days along with chronic restraint stress. Group 6 received a dose of $600 \mathrm{mg} / \mathrm{Kg}$ BB of C. asiatica L. ethanolic extract orally for 21 days along with chronic restraint stress. 


\section{Chronic restraint stress procedure}

After an acclimatization period of one week, chronic restraint stress procedure was conducted. Rats were weighed daily before chronic restraint stress procedure started. The rats were then placed in restrainers for six hours beginning from 09.00 to 15.00 for 21 consecutive days and were kept in their home cages during the restraint period. Vehicle (2\% PGA) or fluoxetine or ethanolic extract was administered 30 minutes before chronic restraint stress for 21 days. The rats normal control were kept undisturbed in their home cages.

\section{Examination of PFC cell proliferation}

Prefrontal cortex cell proliferation was examined by immunohistochemistry method after labelling with a bromodeoxyuridine (BrdU) proliferating cells marker. After chronic restraint stress for 21 days, all rats were injected intraperitoneally with $\mathrm{BrdU}$ (200 mg/kg BW, dissolved in saline). Two hours after BrdU injection, all rats underwent EPM and MWM tests. These tests were repeated once daily for 7 consecutive days. On the $29^{\text {th }}$ day after BrdU administration over, all rats were deeply anesthetized using intramuscularly injection of ketamine and xylazine, transcardially perfused with $\mathrm{NaCl}$ EDTA followed by PBS formalin and then the brains removed and postfixed.

One third of total brain length without cerebellum, from the right hemisphere was processed routinely for paraffin embedding. The block of brain tissue sample was then serially sectioned at coronal orientation at a thickness of $3 \mu \mathrm{m}$ using a Leica microtome (RM 2235). One of 185 slices was randomly chosen to be f1, mounted into IHC slide and coded. The next slices were also stained with cressyl fast violet in order to determine the prefrontal cortex area.
In the cressyl fast violet staining, the tissue was deparaffinized with xylol and then then rehydrated with a graduated alcohol. The tissue was then stained with cressyl fast violet for 2 minutes. If the slices were too dark, the slices were dip in $80 \%$ alcohol. If the slices were too light, the slices were retained in cressyl fast violet. The slices were then dehydrated in $90 \%$ and $100 \%$ alcohol briefly, cleared in xylol and coverslipped with Canada balsam.

For the immunohistochemistry staining, the tissue was deparaffinized with xylol and then rehydrated with a graduated alcohol. After being treated in $3 \% \mathrm{H}_{2} \mathrm{O}_{2}$ in methanol for 20 minutes to block the peroxide, the sections were washed in PBS for three times. The sections were immersed in $0.1 \mathrm{M} \mathrm{pH} 6$ citrate buffer at $80-90^{\circ} \mathrm{C}$ for 20 minutes, washed in PBS and the membrane was permeabilized with $0.25 \%$ trypsin for 10 minutes at $37^{\circ} \mathrm{C}$. After being washed in aquadest for 5 minutes, the sections underwent acidification in $2 \mathrm{~N}$ $\mathrm{HCl}$ at $37^{\circ} \mathrm{C}$ for 20 minutes. To prevent nonspecific binding, the sections were incubated in sniper background for 10 minutes, washed with PBS and incubated in 1:100 primer antibody mouse anti-BrdU (Sigma) overnight at $4^{\circ} \mathrm{C}$. After overnight incubation, sections were adapted in room temperature for 20 minutes before washing with PBS. The sections were incubated with secondary antibody universal link for 10 minutes at room temperature, washed in PBS and incubated in TrekAvidin horseradish peroxidase for 10 minutes before washed in PBS again. After washing, BrdU labeled cells were visualized in 3'-diaminobenzidine (1:50) in substrate for 20 minutes. The sections were washed in aquadest and counterstained with hematoxilin for 2 minutes, washed in aquadest, dehydrated with a graduated alcohol, cleared in xylol and coverslipped with Canada balsam. 
All the BrdU-labeled cells in prefrontal cortex (from the right hemisphere) were counted with $400 \mathrm{x}$ total magnification by equation. ${ }^{15}$

$$
\mathrm{N}=\mathrm{Q} X \frac{1}{\mathrm{f1}}
$$

$\mathrm{N}=$ total cell number,

$\mathrm{Q}=$ cell number of $\mathrm{fl}$,

$\mathrm{fl}=$ sampling fraction $(1 / 185)$.

The cells counted were those showing brown nucleus and nucleolus. Nucleolus was the counting unit. All cells counting were performed by blind method.

\section{Statistical analysis}

The data of the BrdU-labeled cells of all groups were presented as mean \pm standard deviation (SD) and were analyzed using analysis of variance (ANOVA) followed by post-hoc Tukey test. Values of $p<0.05$ were considered statistically significant.

\section{RESULTS}

The reduction in body weights of rats in all groups after chronic restraint stress 6 hours per day for 21 days was observed in this study (FIGURE 1). However, there was no significant difference in the reduction of body weight between all groups ( $p>0.05)$.

\section{Prefrontal cortex area sectioning}

The frontal lobe of right hemisphere of the rats was coronally sliced in $3 \mu \mathrm{m}$. One of every 185 slices was mounted in PLL slide to undergo cressyl fast violet staining. There were 6-8 slices collected in every slide. Cressyl fast violet staining was used to show the area of prefrontal cortex between bregma $+5.64 \mathrm{~mm}$ until bregma $+0.80 \mathrm{~mm}$ containing medial region of prefrontal cortex (mPFC): infralimbic (IL), prelimbic (PL), anterior cinguli $(\mathrm{Cg})$ and orbital region (oFC): ventral and lateral orbital cortex (VO/LO) (FIGURE 2).

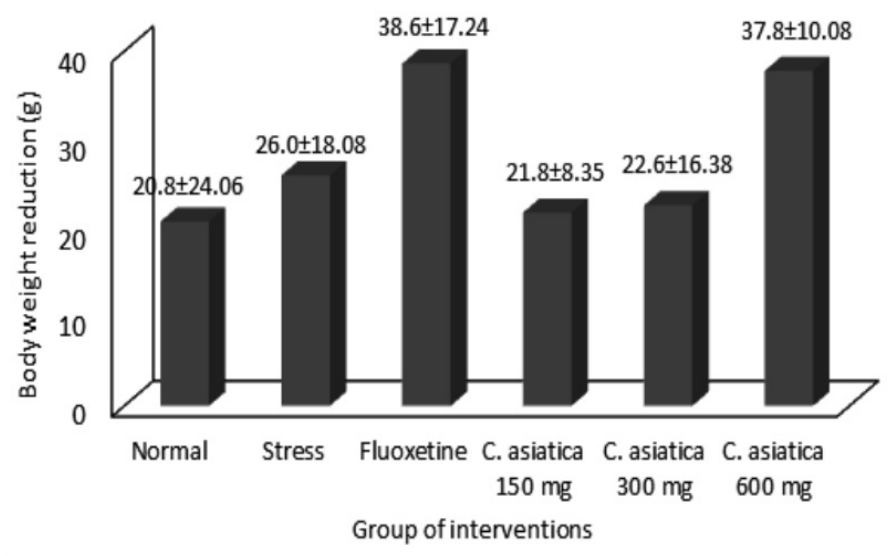

FIGURE 1. Body weight reduction (mean $\pm \mathrm{SD}$ ) of rats in all groups after chronic restraint stress $6 \mathrm{~h}$ per day for 21 days 

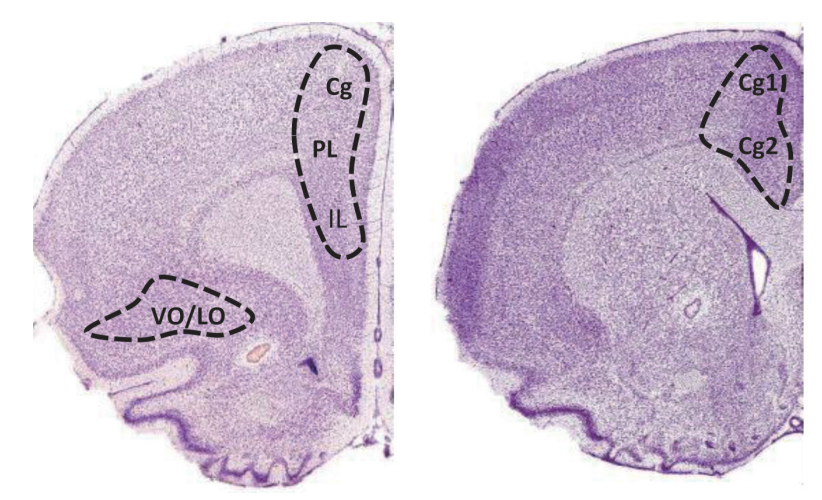

FIGURE 2. Prefrontal cortex area sectioning after cressyl fast violet staining.

\section{Number of BrdU-labeled cells}

The distribution of BrdU-labeled cells in prefontal cortex was examined using the immunohistochemistry method. The BrdUlabeled cells were showed as nuclei with brown color. The BrdU-labeled cells in cluster form that demonstrated mitotic process and in non-cluster form that demonstrated post mitotic process were observed (FIGURE 3). The estimation of total BrdU-labeled cells is presented in FIGURE 4. No significantly difference in the number of BrdU-labeled cells between groups was observed in this study $(\mathrm{p}>0.05)$.
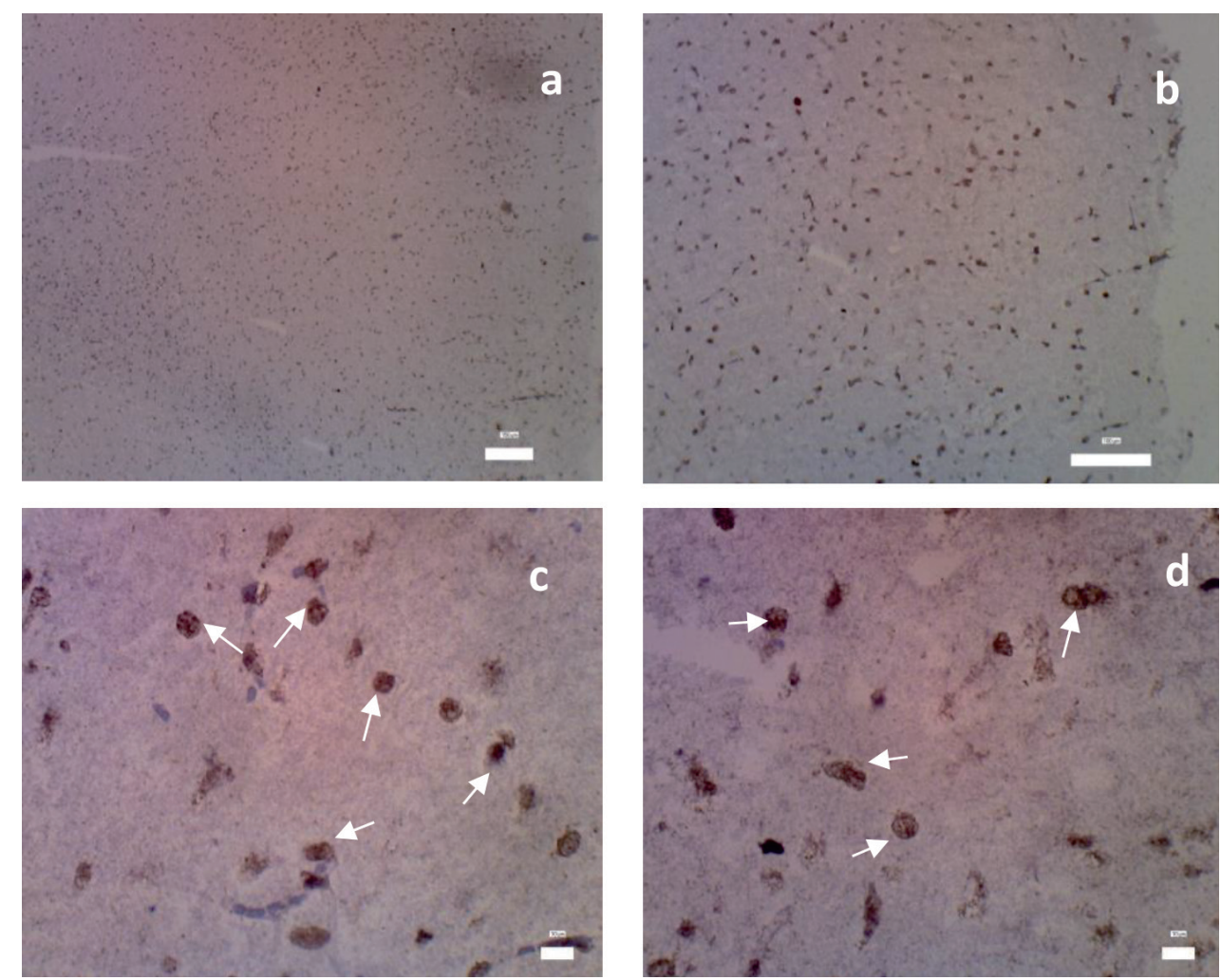

FIGURE 3. The BrdU-labeled cells. $(\mathrm{a}, \mathrm{b})$ distribution of BrdU labeled cells in infra-limbic area (IL), (a) 40x magnification, (b) 100x magnification, (c) the post-mitotic cells in infralimbic (IL) formed in non-cluster cell, (d) IL cells were labeled in mitotic process formed in clustered cells counted as one cell. $b$ dan $\mathrm{c}$ in $400 \mathrm{x}$ magnification, bar scale $10 \mu \mathrm{m}$. The arrow showed positive cell to be counted. 


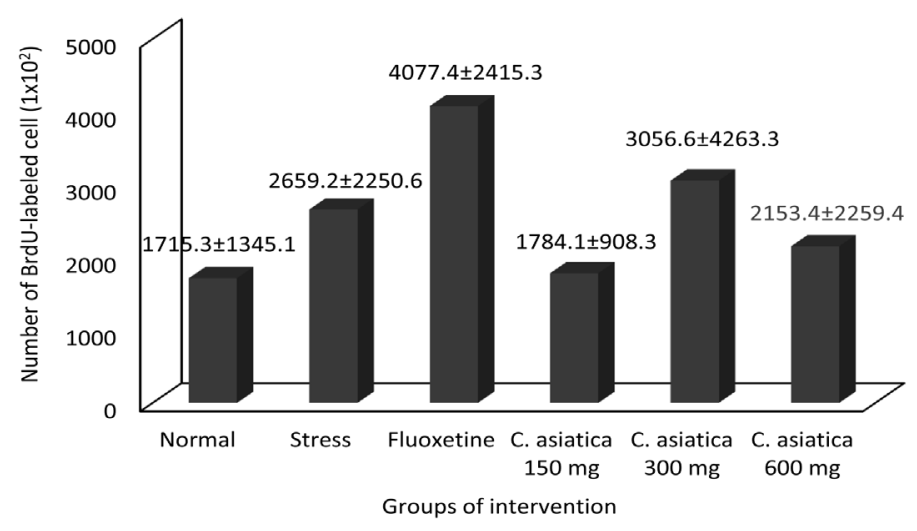

FIGURE 4. Number of BrdU-labeled cell on the right hemisphere of PFC after chronic stress.

\section{DISCUSSION}

\section{Body weights}

The body weight of all rats was weighed daily during 21 days of restraint stress. Reduction in body weight of the rats in all groups was observed in this study, even in the normal control group. The reduction in body weight indicated that all rats had stress experience. The stress experience was also supported by physical appearance of the rats after restraint stress. Rats in all group of treatment expressed pallid, groom, and wet hair of rats after restraint stress. In the normal control group, the stress experience of rats might be caused by oral ingestion of vehicle (PGA) using an oral feeding needle. Seib \& Wellman ${ }^{16}$ reported that daily administration of saline during 21 days increased serum corticosterone level from base line in rats. The reduction in body weight was observed on first 14 days during 21 days of restraint stress. In the beginning of the $3^{\text {rd }}$ week, a trend of increase in body weight was observed. It was assumed that on the $3^{\text {rd }}$ week, rats already adapted to the stress condition.
The reduction in body weight of the rats in $C$. asiatica treatment groups and positive control group (fluoxetine) might be not only due to the stress experience but also due to their side effects. Centella asiatica was reported to have appetite reduction that cause the lowering of food intake. In addition, C. asiatica contains an active compound catechin that can stimulate fats catabolism in the body. ${ }^{17}$ Fluoxetine as positive control has been reported to have appetite loss, body weight reduction and hyperactivity of rats. ${ }^{18}$ The body weight reduction is caused by the increase of serum corticosterone level which have important role in the process of gluconeogenesis. ${ }^{19}$

Although the reduction in body weights of rats tends to be higher after the fluoxetine and $C$. asiatica extract treatment, however no significantly different between all groups was observed in this study.

\section{Prefrontal cortex cell proliferation after restraint stress}

This study showed that the number of prefrontal cortex cell after restraint stress 
(265.920 \pm 225.057$)$ was higher than that normal control or without restraint stress (171.530 \pm 134.510$)$. This result was in contrast to previous findings reported by Czeh et $a l .{ }^{3}$ This authors reported that the number of prefrontal cortex cell after restraint stress was lower that that normal control. Several factors might influence these results. This study was a part of research project concerning the effect of $C$. asiatica on cell proliferation, apoptosis, anxiety, memory and learning. To assess anxiety, the all rats underwent Elevated Plus Maze (EPM) and Morris Water Maze (MWM) tests on the day $22^{\text {nd }}-28^{\text {th }}$ followed by termination on the day $29^{\text {th }}$. These EPM and MWM tests could be a novel stressor on the normal rats which could increase serum corticosterone level higher than on the rats that underwent restraint stress before. ${ }^{19}$ Corticosterone is a down-regulator of cell proliferation. ${ }^{8}$ The high serum corticosterone level will suppress the production of new born cells in prefrontal cortex as indicated by the decrease of the number BrdU-labeled cells. ${ }^{20,21}$

\section{Prefrontal cortex cell proliferation after treated with $C$. asiatica}

This study showed that the number of BrdU-labeled cells between groups was not significantly $(p>0.05)$. This result demonstrated that the administration of ethanolic extract of $C$. asiatica did not increase cell proliferation on prefrontal cortex of rats. This results are not supported by the previous studies reported by some authors. Centella asiatica $\mathrm{L}$ has been used traditionally as antidepressant for a long time. ${ }^{11}$ Moreover, the ethanol extract of $C$. asiatica $\mathrm{L}$. has been proven to have sedative effect and can increase cognitive functions in animal model. ${ }^{12}$ This plant has also anti-inflammatory active constituents that can stimulate proliferation in healing injury, ${ }^{13}$ and increase brain's higher function in young and adult mice. ${ }^{14}$

As above mentioned that the EPM and MWM tests performed to the rats during this study could increase serum corticosterone level and lead decrease the prefrontal cortex cell proliferation as indicated by the decrease of the number BrdU-labeled cells..$^{20,21}$

\section{CONCLUSION}

In conclusion, the administration of ethanolic extract of $C$. asiatica does not influence cell proliferation on prefrontal cortex of rats after chronic stress. The functional test conducted during in this study might influence the cell proliferation.

\section{ACKNOWLEDGMENTS}

The authors would like to thank Dr. Rina Susilowati, Ph.D from Histology and Cellular Biology Department of Faculty of Medicine, Dr. drh. Tri Wahyu Pangestiningsih, M.P, from Department of Microanatomy, Faculty of Veterinary, Universitas Gadjah Mada for their support on histology consultation and Mr. Tomiyoshi Setsu, Ph.D from Anatomy and Developmental Neurobiology, Kobe University for his support on immunohistochemistry methods and protocols.

\section{REFERENCES}

1. Garret JE, Wellman CL. Chronic stress effect on dendritic morphology in medial prefrontal cortex: sex difference and estrogen dependence. Neuroscience. 2009; 162(1):195- 207. http://dx.doi.org/10.1016/j. neuroscience.2009.04.057

2. Kendler KS, Karwoski LM, Prescott CA. Causal relationship between stressful life events and the onset of major depression. Am J Psychiatry. 1999; 156(6):837-41. 
http://dx.doi.org/10.1176/ajp.156.6.837

3. Czeh B, Muller-Keuker JI, Rygula R, Abumaria N, Hiemke C, Domenici E, et al. Chronic social stres inhibit cell proliferation in the adult medial prefrontal cortex: hemmispheric asymmetry and reversal by fluoxetin treatment. Neuropsychophamarcol. 2007; 32(7):1490-503. http://dx.doi.org/10.1038/ sj.npp. 1301275

4. Wellman C. Dendritic reorganization in pyramidal neurons in medial prefrontal cortex after chronic corticosterone administration. J Neurobiol. 2001; 49(3):245-53. http://dx.doi.org/10.1002/neu.1079

5. Dias-Fereira E, Sousa JC, Melo I, Morgado $\mathrm{P}$, Mesquita AR, Cerqueira JJ, et al. Chronic stress causes frontostriatal reorganization and affect decision making. Science. 2009; 325(5940):621-5. http://dx.doi.org/10.1126/ science. 1171203

6. Davidson RJ. Anxiety and affective style: role of prefrontal cortex and amygdala. Biol Psychiatry 2002; 51(1):68-80. http://dx.doi. org/10.1016/S0006-3223(01)01328-2

7. Clark L, Cools R, Robbins TW. The neuropsychology of ventral prefrontal cortex: decision-making and reversal learning. Brain Cogn 2004; 55(1):41-53.

http://dx.doi.org/10.1016/S02782626(03)00284-7

8. Duman RS, Malberg J, Nakagawa S. Regulation of adult neurogenesis by psychotropic drugs and stress. J Pharmacol Exp Ther 2001; 299(2):401-7.

9. Malberg JE, Eisch AJ, Nestler EJ, Duman RS. Chronic antidepressant treatment increases neurogenesis in adult rat hippocampus. J Neurosci 2000; 20(4):9104-10.

10. Mamedov N. Adaptogenic, geriatric, stimulant and antidepressant plants of russian far east. J Cell Mol Biol 2005; 4:71-5.

11. Kurniawati A, Darusman L, Rachmawaty. Pertumbuhan, produksi dan kandungan triterpenoid dua jenis pegagan (Centella asiatica L. (Urban)) sebagai bahan obat pada berbagai tingkat naungan. Bull Agron 2005; 33:62-7.
12. Veerendra Kumar MH, Gupta YK. Effect of Centella asiatica on cognition and oxidative stress in an intracerebroventricular streptozotocin in model of alzheimer disease in rats. Clin Exp Pharmacol Physiol 2003; 30(56):336-42. http://dx.doi.org/10.1046/j.14401681.2003.03842.x

13. Cheng CL, Guo JS, Luk J, Koo MWL. The healing effects of Centella asiatica extract and asiaticoside on acetic acid induced gastric ulcers in rats. Life Sci 2004; 74(18):2237-49. http://dx.doi.org/10.1016/j.lfs.2003.09.055

14. Rao S, Chetana M, Uma Devi P. Centella asiatica treatment during postnatal periode enhances learning and memory in mice. Physiol Behav 2005; 86(4):449-57.

http://dx.doi.org/10.1016/j.phys beh.2005.07.019

15. Horward CV \& Reed M. Unbiased stereology: three-dimensional measurement in micros-copy. Abington UK:Garland Science/ BIOS Scientific Publisher, 2005.

16. Seib LM \& Wellman CL. Daily injection alter spine density in rat medial prefrontal cortex. Neuroscience 2003; 337:29-32.

http://dx.doi.org/10.1016/s03043940(02)01287-9

17. Hussin M, Abdul-Hamid A, Mohamad S, Saari N, Ismail M, Bejo M. Protective effect of Centella asiatica extract and powder on oxidative stress in rats. Food Chem. 2007; 100:535-41. http://dx.doi.org/10.1016/j. foodchem.2005.10.022

18. Czeh B, Meuller-Keuker JIH, Rygula R, Abumaria N, Hiemke Chr, Dominici E, et al. Chronic social stress inhibit cell proliferation in the adult medial prefrontalis cortex: hemispheric asymmetry and reversal by fluoxetine treatment. Neuropsychopharmacol 2007; 32: 1490-503. http://dx.doi.org/10.1038/ sj.npp. 1301275

19. Marin MT, Cruz FC, Planeta CS. Chronic restraint or variable stresses differently affect the behavior, corticosterone secretion and body weight in rats. Physiol Behav 2007; 
90(1):29-35. http://dx.doi.org/10.1016/j. physbeh.2006.08.021

20. Banasr M, Valentine GW, Li XY, Gourley SL, Taylo JR, Duman RS. Chronic unpredictable stress decreases cell proliferation in the cerebral cortex of the adult rat. Biol Psychiatry 2007; 62(5):496-504. http://dx.doi. org/10.1016/j.biopsych.2007.02.006
21. David DJ, Samuel BA, Rainer Q, Wang JW, Marsteller D, Mendez I, et al. Neurogenesis-dependent and-independent effects of fluoxetine in an animal model of anxiety/ depression. Neuron 2009; 62(4):479-93.

http://dx.doi.org/10.1016/j.neuron.2009.04.017 